\title{
The impact of European policies towards science and technology on the European research landscape
}

Citation for published version (APA):

Backhaus, J. G. (1996). The impact of European policies towards science and technology on the European research landscape. METEOR, Maastricht University School of Business and Economics. METEOR Research Memorandum No. 031 https://doi.org/10.26481/umamet.1996031

Document status and date:

Published: 01/01/1996

DOI:

10.26481/umamet.1996031

Document Version:

Publisher's PDF, also known as Version of record

\section{Please check the document version of this publication:}

- A submitted manuscript is the version of the article upon submission and before peer-review. There can be important differences between the submitted version and the official published version of record.

People interested in the research are advised to contact the author for the final version of the publication, or visit the DOI to the publisher's website.

- The final author version and the galley proof are versions of the publication after peer review.

- The final published version features the final layout of the paper including the volume, issue and page numbers.

Link to publication

\footnotetext{
General rights rights.

- You may freely distribute the URL identifying the publication in the public portal. please follow below link for the End User Agreement:

www.umlib.nl/taverne-license

Take down policy

If you believe that this document breaches copyright please contact us at:

repository@maastrichtuniversity.nl

providing details and we will investigate your claim.
}

Copyright and moral rights for the publications made accessible in the public portal are retained by the authors and/or other copyright owners and it is a condition of accessing publications that users recognise and abide by the legal requirements associated with these

- Users may download and print one copy of any publication from the public portal for the purpose of private study or research.

- You may not further distribute the material or use it for any profit-making activity or commercial gain

If the publication is distributed under the terms of Article $25 \mathrm{fa}$ of the Dutch Copyright Act, indicated by the "Taverne" license above, 
THE IMPACT OF EUROPEAN POLICIES TOWARDS SCIENCE AND TECHNOLOGY ON THE EUROPEAN RESEARCH LANDSCAPE 


\begin{abstract}
In this essay, I have tried to show that the European Union inititiatives towards science and technology, ostensibly in the interest of promoting employment and growth through technological advancement, have side effects that undermine the very purpose at which they aim. The funding formula and the way the programs are launched undermine the ability of leading research universities to be leading players in the international fields that is, of course, not dominated by European Union research priorities. The only way to make the program successful is, indeed, to make it universal, which is out of the question. More specifically, we have taken note of a number of points which are worth taking stock of at the end of this long essay. They do not quite reveal the impact of the argument, but some preliminary statements may well be formulated on the basis thereof.
\end{abstract}




\section{Zusammenfassung}

Dieses Kapittel gilt der Politik der Europäischen Union im Hinblick auf Technologie und Forschungsfragen. Die Fragestellung wird auf die traditionelle forschende europäische Universität eingegrenzt, die im deutschen Sprachraum mit dem Humboldtschen Ideal beschrieben wird.

Es wird auf Grund eines ökonomischen Modelles gezeigt, daß diese Universität als System zwar begreifbar, aber im Einzelnen schwer modellierbar ist. Ihre Effizienz roht in der umsichtigen Beobachtung von erwarteten Rollen, Prozeduren, Akten mit ihren Vorgängen und einem bestimmten Comment wissenschaftlicher Arbeit, der die Publikation der Forschungsergebnisse gewiß verlangt, aber nicht die Formen vorschreibt, in denen diese Publikation erfolgt.

Unter der Annahme, daß Universitäten vor allem (volkswirtschaftlich gesehen) öffentliche Güter und Externalitäten produzieren, wird weiter der Frage nachgegangen, wie sich die Politik der Europäischen Gemeinschaft auf die universitäre Landschaft in Europa auswirkt. Idealtypisch wird an die traditionelle Humboldtsche Universität gedacht. In dem Aufsatz wird im einzelnen ausgeführt, welche erheblichen Verschiebungen und zum Teil auch

Verwerfungen die europäische Politik bewerkstelligen kann, und es wird auch auf einige Beispiele eingegangen, bei denen dies wahrscheinlich jetzt schon abzusehen ist. 
THE IMPACT OF EUROPEAN POLICIES

\section{TOWARDS SCIENCE AND TECHNOLOGY ON}

\section{THE EUROPEAN RESEARCH LANDSCAPE}

Chapter prepared for inclusion in:

Sabine Urban (ed.), Europe's Challenges: Economic Efficiency and Social Solidarity, Wiesbaden: Gabler, 1996, pp. 247-290

J.E.L. code: H4, I28, O31 
THE IMPACT OF EUROPEAN POLICIES

\section{TOWARDS SCIENCE AND TECHNOLOGY ON}

THE EUROPEAN RESEARCH LANDSCAPE

\section{Table of Contents}

I. Introduction and overview

II. The economic basis of the traditional research university

III. Competition among scholars and institutions

IV. The concept of order in law, economics and scholarship

V. Communication and scholarship

VI. Minimal functional requisites for an order of scholarship

VII. Critical aspects of European policy goals

VIII. Critical aspects of European policy instruments

IX. Performance and its evaluation

$\mathrm{X}$ Internationalization and rating

XI. Alternative approaches

XII. Towards some tentative conclusions

References 


\section{Introduction and Overview}

European policies towards research in science and technology cover research carried out at research based commercial companies, research based non-profit institutions and the traditional research universities which also have a teaching mission. While the commercial research based companies obviously compete among each other on commercial markets ${ }^{1}$ and while the not for-profit research institutions with specific research objectives tend to also internationally compete with each other, for instance in processes of public tender offerings, the different Member States of the European Union have developed and still maintain very different university systems that communicate very little one with the other. For instance, professorial mobility is very low between the different university systems, when it can be very high within a particular university system. For instance, the German language area can be said to have developed one type of university system, with similar and comparable degrees, high professorial mobility and common media of publication. The British system, on the other hand, certainly in the postThatcher years has developed a very specific and own style and professorial mobility is strongest with the university landscapes of non-European Union Member States such as the United States and Canada. The French maintain a largely separate system, and so do other Member States of the European Union. Within each of these systems, there is competition for resources, but this competition can take on very different forms. When the European Union identifies its policies towards research based institutions such as the research universities, they will respond to the incentives developed through European Union policies in very different ways, depending on their own structure, mission and the rules of their system within which they are operating. These rules are typically embodied in complex legislation on university organization, as most Member States of the European Union maintain a large state university system with very few exceptions for private institutions. The missions even of the research universities in the different Member States of the European Union tend not to be identical.

Each of these systems has developed its own forms of communication, its own forms of competition and its own style of existence. As a common policy of the European Union now adds to the traditional purposes, functions and styles of performance, friction can occur between the intended objectives of the European policy initiatives and the traditional missions of the research institutions to which these initiatives are being addressed. The purpose of this chapter is to explore the possibility of such frictions, their likely cause and possible remedies.

The chapter starts by discussing the economic basis of the traditional European research university (II). This leads to a discussion of forms of competition between scholars and institutions. Competition can take on a certain form, and the concept of order in law, economics and scholarship is introduced in order to discuss the different forms competitive processes among research institutions and scholars can take. An important element of each order of scholarship is communication, which is discussed in the following paragraph (V). Minimal functional requisites for an order of scholarship are discussed (VI) in order to have a backdrop for an

1 Sometimes, the research departments of commercial companies also compete with university research institutions, for instance for publication space and scholarly honors, such as the Nobel prizes. 
overview over critical aspects of European policy goals (VII) and critical aspects of European policy instruments (VIII). Ultimately, any science policy aims at improving the performance of the institutions which it addresses. This is why performance and its evaluation is necessary to be addressed in this context in order to understand how science policies such as the European science policies work (IX). One of the aspects of European science policy is the internationalization of scholarship and the opening of the different university systems; inevitably, in conjunction with the necessary evaluation of science policies, this involves the concept of rating the different institutions thus affected (X). Rating, however, can have disastrous consequences, in particular in the long run, which is why alternative approaches need to be considered (XI). The chapter ends with some tentative conclusions (XII).

This chapter builds on a body of literature emphasizing the concept of an order underlying economic processes. This literature, based on the work of Eucken and the Freiburg school, is almost exclusively available in German. A secondary goal of this chapter is to make this literature better available to an international audience by showing how it can be applied to a core problem of European Union policy and how the results of the application of this body of scholarship differ from the available literature.

\section{The Economic Basis of the Traditional Research University}

In the interest of strengthening the competitiveness of the European economies through technological leadership and thereby also in the interest of growth and employment, the European Union has increasingly become involved in the area of policies towards science and technology. The basis for these policies can be found in the Treaty of Maastricht in article 130 $(\mathrm{i}, \mathrm{k})$, where scope and realm of such policy programs are being described in broad terms. The changing scope, form and structure of financial and other incentives, the latent tension between furthering co-operation in the interest of technological leadership on the one hand, and the strengthening of the competitive order on the other shall not be addressed in this essay. Here, we shall only take as an institutional given that the European Union through Council and Commission is active in the field of policy in the area of science and technology (broadly conceived): that the Union thereby addresses largely institutions that are either private or public and not located at the level of the European Union: that the policy works through programs that bundle specific particular interests in identifying research priorities: ${ }^{2}$ and that these policies offer financial incentives designed to change the behavior of the institutions, both private and public, engaged in research and development.

With this very parsimonious set of assumptions in place, we can turn to a stepwise analysis of the impact of European policies on the European research landscape, where the emphasis will be on that part of the European research landscape in which public and not for profit organizations have historically operated and which they have dominated. The area of commercial research and development, such as in the areas of air, space, atomic energy, other energy,

2 A good institutional description of the policies with both a historical survey and a theoretical analysis can be found in Joachim Starbatty and Uwe Vetterlein, "Forschungs- und Technologiepolitik in der Europäischen Union", Tübingen: Wirtschaftswissenschaftliche Fakultät, 1994 (Diskussionsbeitrag Nr. 39). 
pharmaceutical research etc. is certainly important but not the focus of this chapter. With "European research landscape" we primarily mean research carried out in nationally and internationally competing universities and similar institutions of research and higher learning.

The "traditional research university" is the second term, introduced in the outline, that requires further precision. Ever since the first universities were founded in Europe in Salerno (1050), Bologna (1119), Paris (1150) and two centuries later in Germany, Prague (1348), Vienna (1365) and Heidelberg (1386), several dominant characteristics can be emphasized which do not describe any single one institution at every point in time since its inception until now, but can be held to describe the European research university as an ideal type (Max Weber). Sanctioned by papal, imperial or later other state decrees and charters, the traditional European research university is a community of scholars and students jointly enjoying a high degree of autonomy (originally their own citizenship and jurisdiction) in the interest of preserving the traditional academic freedoms and allowing the universities to govern themselves, as their specific mission often put them at variance with the modus operandi of the immediate environment. The product of the university consists in the instruction and grooming of future scholars who will help in preserving traditional knowledge and improving upon it by means of research and learning. The process requires a high degree of self-regulation, as this is the main form of quality control. Internally, the functional distinctions in the traditional research universities are based on the one hand on the relative advancement in scholarship, as both students and teachers in their various stages of progress jointly form part of the body (therefore called) university. Secondly, the traditional form of organization emphasizes the different areas of specialization originally organized in the different faculties. It is symptomatic for the operation of a traditional research university that its decisionmaking is organized in terms of these faculties or areas of specialization, which means that the endowment with resources different researchers enjoy depends both on their status within their discipline and the status of the discipline within their university. The latter is typically path dependent.

As the output of the university consists in very few tangibles and mainly in public goods and externalities, it is difficult to measure; and for that reason performance evaluation tends to be input oriented rather than output oriented. The input is then typically measured in terms of time and the fulfilment of specific requirements, in the case of education the sequence of examinations, in the case of instruction frequence, length and timing of lectures and other forms of education, in the case of research the passage of certain tests and procedures of quality certification, such as public defenses, requirements to publish research results, competitions for specific prizes announcing problems to be solved etc. These forms have during the last century become much more variegated and also almost routinely being employed, a process and some features thereof are discussed in more detail in sections 9 and 10.

Since so much of the emphasis on performance measurement had traditionally to be put on inputs and the meeting of certain formal criteria, the revenues of the university would also be related to rough input measures such as student enrollment, granting of degrees, certain academic events etc. with a heavy reliance on fees (for immatriculation, for lectures, for degrees) and independent forms of revenues. In particular, those universities founded in Germany after the Reformation were often given substantial endowments taken from deconstituted church institutions. ${ }^{3}$

3 The university of Marburg (Lahn) is such an example. 
Similarly, the large wave of university foundations according to the Land-Grant Act (1862; 1890 ) in the United States more than a century ago endowed the universities with (typically undeveloped) land in order to fulfil their (in the United States three) missions of education, research and extension.

This form of funding points to an aspect which has always been at the heart of university related economics, and which also plays a role in the current European Union policies towards science and technology. The public goods and externalities produced by universities, although not directly marketable, are nevertheless very valuable, which is the reason why universities were often founded as part of an economic development strategy. ${ }^{4}$ Some of these externalities can be captured indirectly, if the university is endowed with assets upon which its production has a positive (external) impact. The function of extension work (essentially amounting to developing agriculture, industry and trade in the area around the university) provides an example for such an impact. The more successful the land-grant university has been at this extension, the more valuable the land it owns and the higher the revenue it can derive therefrom.

Most European research universities at present do not have significant own endowments. In this sense, they contrast significantly with many American institutions. ${ }^{5}$ Consequently, most European universities depend on budgettary allocations that were until recently largely dependent on the general fiscal situation of the state in question and input related criteria relating to the specific university, such as enrollment, staff, specific on campus institutions etc. With the increasing use of different funding formulae such as those used in the European programs, increasingly reliance on matching funds and attempts at designing performance related budgets, the traditional research university may experience tensions and challenges that question some of the basic characteristics outlined in this section.

Although universities, and we shall further assume that they roughly fit the stylized institution of the traditional European research university, do not directly compete in the market place as they are resigned to producing essentially public goods and externalities, they are nevertheless and always have been very competitive both in terms of universities competing one with the other and in terms of internally providing for a competitive environment among the students and scholars of which they are composed. These types of competition, however, tend to have very different forms and features from what is typical outside the traditional academic environment. Outside the traditional university environment, probably the most important forms of competition are price competition and product competition, essentially that type of competition

\footnotetext{
4 Most German universities founded after 1648 clearly fall into this category.

5 In the United States, even small colleges sometimes boast impressive endowments. Berry College in Rome, Georgia founded by Martha Berry at Mount Berry in 1902, with a student body of barely 1,000 enjoys an endowment well in excess of $100,000,000$ dollars. In addition to receiving undergraduate and graduate education, students also receive vocational training in one of the various college related enterprises, some of which have been able to launch innovative products nationwide. The case points to the viability of well endowed institutions of higher learning without state support.
} 
through product innovation and the distinguishing characteristics of new or different products from those of the competitor. Inside the university and between the universities, competition has always taken on very different forms. Competition for students has sometimes been fierce, even so fierce that for instance the electors and later kings in/of Prussia had to take measures to regulate competition between their various state universities. ${ }^{6}$

In competing for students, universities found themselves in agreement with the leaders of their respective host cities, who would profit from the presence of students due to increased industry and trade. The different teachers at the university, however, typically also competed for students among each other, although in this context competition by definition always had to be among the few, since there would only be very few professors teaching the same subject matter. That is why this form of competition could likewise become acrimonious and has always been regulated by university bodies to some extent.

As long as we have known the institution of the university, teachers there have drawn largely different (net) incomes. These are not only income differences as between the different universities, but also income differences between the different faculties in the university and furtheron income differences within the same faculty, even if rates were the same. This has to do with the fact that there have always been different sources of income not only for the universities themselves, but also for their members. For instance, the traditional German university of the eighteenth and nineteenth century emphasized lecture fees and sales from books as the main form of income often well in excess of professor's salaries. Hence, the successful university professor would devote most of his attention to preparing lectures and keeping his one or several textbooks in print. Consequently, research would be transported through the textbooks, which then had the dual purpose of preserving and keeping the existing knowledge available and adding new insight. With the advance of the technical sciences to the university research landscape during the nineteenth century on the European continent and somewhat later in Britain, revenues from new inventions and developments, patents etc. became increasingly important, but remained special features of the technical universities or the technical faculties where those existed in the traditional universities. Where marketable services could be combined with the university mission, such as in the new technical sciences, in chemistry or in medicine, dual appointments of professors to university chairs and as directors to institutes in their fields, with the institutes or hospitals generating fees for services, became increasingly more important, notably during the late nineteenth and during the twentieth century. In all these cases, the competition for resources always took the form of highly regulated processes of quality certification and distinction. ${ }^{7}$

In trying to enhance its reputation, the university or the faculty in the university would emphasize signs of quality and excellence through procedural means. As an example, in order to

6 It is noteworthy that they would certainly not assign students to the different institutions of higher learning, as modern governments do, but rather moderate excesses of disparaging each other's reputation by issuing decrees in which they emphasized positive aspects of their various institutions.

7 Other professions that also primarily provide public goods and externalities have developed strikingly similar procedures to those described here for the (ideal type) European research university. For Spanish notaries public see Benito Arruñada, "The Economics of Notaries", European Journal of Law and Economics 3, (March) 1996, pp. 5-37. 
distinguish the law school in Göttingen and the medical faculty in Berlin, the Prussian university administration (at the behest of Althoff) issued a decree requiring enhanced $\mathrm{PhD}$ requirements consisting of oral examination and the obligation to print the dissertation (implying that there had to be one) which temporarily lead to the odd situation that two thirds of all doctoral candidates in law concentrated at the non-Prussian universities of Leipzig, Heidelberg and Jena. The medical students showed a similar reaction. Yet, in due course, all the faculties and universities had to follow suit and insist on similar requirements of publicity, as they had to compete through their perceived reputation. This is only one instance of an entire history of similar regulatory and procedural refinements all intended to emphasize fairness in competition when the quality of output is difficult to measure. Next to the publication of doctoral dissertations and public examinations throughout, open competition for university positions and the prohibition of inhouse promotions (which are known to lead to nepotism) form part of this heritage of reputation preservation. It should be emphasized that in no known case was there an emphasis on trying to organize the competitive process around particular topics of inquiry of themes of research, as such an attempt would necessarily skew competition in terms of specific prior advantages.

Two aspects of European initiatives vis à vis the traditional research university are relevant in this context. The European initiatives try to indeed identify particular topics and very often also prescribe research methodologies. In this way, the field of competition is often reduced to very few possible entries. This has the obvious short term effect of providing a wind fall advantage to the researchers thus privileged. This intended short term effect, however, is bought at a very substantial long term price.

Similarly, in an apparent attempt at stimulating innovation in the European universities, the socalled Monnet professorships have been set up in such a way that they typically require inhouse promotion and limited publicity for the competitive process. The procedure flies in the face of traditional university appointment rules, and, again, next to the intended effects of benefiting a particular group, has the potential of long term negative consequences as appointment rules form part of the institutional capital the traditional research university has developed in order to safeguard and protect its reputation.

\section{IV.}

The last two examples have been introduced here primarily in order to raise the issue of whether in the interest of achieving a particular result (such as an emphasis on particular research areas or the rejuvenation of a generation of the professorate of universities considered by some criterion as too old) the European Union through its program initiatives may be well advised and in her right or whether these policies may carry with them hidden costs that would make them a subject of criticism and conceivably rejection.

Since on the face of it, the policies typically require some type of consensus of the implementing Member State, they should not be found to impose costs other than those weighed against the benefits prior to their implementation. This view is the standard view not only held in most quarters in Brussels, but also in the capitals of Member States, in the capitals of federal states where these are responsible for university policies, and last but not least in the administrations of many universities. The difficulty, however, lies in the fact that neither are most of the 
customs that govern academic behaviour nor the procedures and traditions by which a university attains its goals very well understood from a functional point of view. The university is an institution that in Europe embodies the experience of almost a millenium, a period of time which transscends most people's imagination. During this time, enormeous revolutions in culture, thought, experience and aspirations of European people have taken place, many institutions have been shaken to their foundation or even long-disappeared, yet the university with its peculiar rules and procedures has prevailed in the midst of very different environments and faced by many different challenges. When in a particular country its structure had been temporarily de-naturated, such as in pre-World War II Germany or in the countries of the former state socialist regimes based on Marxism/Leninism, old university structures have been revived and re-built upon, as if no other alternatives had ever existed. Probably, this is best interpreted in terms of Hayek's approach to economic policy. When economic policies have widespread and often unintended consequences, we should not pretend foresight but rather plead ignorance and avoid breaking up structures the functions of which we poorly understand. In this general sense, it is probably a safe rule of policy to only use such policy instruments which exhibit a good functional fit with the institutions to which they are addressed. This is still a very modest suggestion, but it can be augmented upon. In its more sophisticated appearance, the approach referred to here is the so-called ORDO school of analysing economic systems comparatively, the university landscape being such a system. By taking a systems' approach, the school was able to derive a set of necessary conditions for a competitive order originally in the context of the market economy, but in principle generalizable to any kind of competitive order. These conditions taken together as a whole form the framework for the competitive order, i.e. the constitution of the system, and the operation of the system is greatly facilitated if the conditions can be found among the constituting elements by which the system abides. For the economic system of the market economy, these basic constituting elements have been identified as 1 . freedom of contract: 2 . guaranty of private property: 3 . the synchronization of control and liability: 4. constancy and predictability of economic policy: 5 . the provision of a stable currency and 6 . open access to markets. ${ }^{8}$

In the interest of space, I should not like to develop the intricacies of this theoretical approach as far as the economic system goes. In this context, we are primarily interested in conditions that can govern competition in progress in the university landscape of research institutions, which, as we have seen above, have to follow somewhat different rules from those observed in the corporate world, as they are primarily engaged in the production of public goods and externalities and cannot engage in market exchange: in fact, for some time now in Europe, these institutions have been state sponsored and it may therefore seem surprising that the same theory of a market order should also apply to the landscape of research institutions.

In fact, it is not difficult to translate the six criteria into the relevant constituting elements that have to govern a university landscape, and this is why I should like to sketch a short approximation in what follows.

In the market economy, freedom of contract governs the way exchange can take place. It is primarily the notion of free choice of exchanging partners, the freedom of choice over what is

8 See e.g. Wernhardt Möschel, "Corporation Policy from an ORDO Point of View". Chapter 7 in: Alan Peacock and Hans Willgerodt (eds.) German Neo-Liberals and the Social Market Economy, New York: Saint Martin's, 1989, pp. 142-178 (154-155). 
to be exchanged, the conditions under which the exchange takes place, the terms of the exchange relationship and their duration, the issue of whether or not to enter into a long term exchange relation, and which aspects to exchange and which to withhold.

For the exchange (of ideas) between scholars, all these aspects have relevance. In scholarly exchange, the consideration of the good offered is in fact just this: the consideration. An idea is being offered, and taking it up either to reject or to further build on it and acknowledge it by citation provides for a completion of the exchange.

Since most ideas published remain unconsidered, unacknowledged and often unread, finding an audience for the scholar is as important as arriving at the idea or concept governing her inquiry, in the purely functional sense of effective communication. Accordingly, the choice of the form in which an idea is to be presented, be it as a book, an article, an experiment, a demonstration etc. is intrinscally tied into the choice as to what to research. Research design and publication strategy are two aspects of the same activity, and in the traditional university dominated research landscape they have been part of the freedom of doing research (academic freedoms) in order to safeguard the effective flow of communication. It will appear later that the European Union policies towards science and technology impact on this basic set of freedoms.

The guarantee of private property in the market place does not imply that there be only private forms of property and no forms of collective property. Of course, the university research landscape is dominated by collective forms of property, and so care has to be taken with the definition of this constituent element. In the context of market exchange, the guarantee of private property rights implies that for each resource there be a one to one relationship between the resource and a right pertaining to it. Rights may, of course, be jointly exercised but in this case a clear decision rule has to govern the distribution of fruits from the co-exercise and the allocation of consequences, i.e. liability.

In the case of the exchange of ideas in the university basic ${ }^{9}$ research landscape, collective property rights translate into private claims primarily when it comes to access to common property resources. Such common property resources include: the stock of knowledge available, the stock and flow of data available, access to research relevant papers and findings, decisions, cases, policy documents etc., rights to offer one's findings and make them part of the common domain, and as ancillary rights rights to exchange ideas, rights to travel, carry a passport and library card, rights of computer network usage, etc.

Only if the participating scholars and scholarly institutions are roughly endowed with the same bundle of rights can an unstrategic process of scholarly communication take place and continue.

Synchronization of control and liability requires that those who are responsible for taking decisions also be those who face the consequences. In the market context, this constitutes the principle of liability. In the research university landscape, such an institute of liability has not yet developed. It is not clear whether it can develop, because the process of scientific exchange and discovery requires a certain amount of error in order to be productive. It is through the launching of conceivably erroneous statements and their (backing) reputation that progress is being made in scholarly pursuit. For that reason, liability in this context has been limited to the

$9 \quad$ Different considerations apply when applied research is being carried out. 
case of being proven wrong, which has always carried (negative) sanctions for the scholar or group of scholars who have commited the error and conceivably also for the institution of which they are a part. Beyond this, there is no liability for errors, as the benefits from correct insight are also limited. They are in the public domain. The whole enterprise of scientific communication and discovery is a co-operative and to that extent collective one, and therefore individualized sanctions have to be limited in order not to bring the entire system to a grinding halt.

Yet, a fairly recent development has occurred in that a large part of the daily decisions that used to be made by scholars are now routinely made by university administrators who are not responsible for the scholarly consequences of their action or non-action.

This phenomenon started less than a hundred years ago, and it is directly relevant to the issue at hand, since the European Community routinely works through the university administration and not with scholars individually or collectively: this is not surprising, since the European Community is a bureaucracy itself, and not a scholarly enterprise. These joint decisions and the consequences thereof, however, can lead to a serious impairment and conceivably a breakdown of the scholarly community, the reliability of interchange and the unquestionability of scholarly motives in entering into scholarly communication.

Constancy and consistancy of economic policy vis á vis the market has its immediate counterpart in the requirement that policies towards university research landcapes be constant and consistent as well. The reason here is straightforward and absolutely similar to the case of market exchange. Constancy and consistancy in economic policy is a necessary element of the social system or order for expectations of the future to be as accurate as market vicisitutes may permit. These expectations drive investment decisions. The more investment intensive a particular industry, the more vulnurable it will be with respect to changes in economic policy. In the market economy, agriculture and the construction industry are cases in point. In agriculture to this very day, there are investment decisions which have to be taken, by their very nature, sometimes over several generations. The diversions between long term and short term marginal costs in that sector can be immense, which means that the next generation may suffer in its ability to carry on the farm business if a previous generation has committed a serious error and locked it into an operation with low marginal and high average costs. Similarly, construction and ship building, not to speak of forestry require constancy in economic data in order to be carried on in a viable way.

The university research landscape is not different from those industries. Actually, in some ways it is even more vulnerable to political vicissitudes without immediately showing signs of crisis when entring a critical indication.

The reverse is also true. Due to the same benefit/cost configuration, universities hold out political rewards in terms of employment and economic growth for quite some time (at least 612 years) when the political benefacters have long left the scene. As a political trough of agrital, universities are for the very long vere.

Mistakes made in one generation often haunt three generations later and benefits from prudent decisions may not be visible during the generation when the prudent decisions have actually been made. A lot of the capital of university institutions is locked into past decisions, procedures, collections, research designs and personel policy. Adopting a research program is a strategic choice for a young scholar, and she may be "married" to that research paradigm longer than she is to her husband. After all, "divorce" implies writing down one's human capital to nothing or next to nothing, and such decisions are not easily taken. Neither individu- 
als nor entire institutions can readily get away with making serious mistakes. Mistakes may not be avoidable if the environment in which decisions have to be taken is constantly changing. Hence, constant changes in policies towards research universities and those policies that otherwise impact on the landscape in which research universities operate, are likely to have very long term consequences which are very difficult to document in the short term when these decisions are being taken. Still, the overall impact can be very big.

The provision of a stable currency is not, even in economic terms, the requirement to provide a single currency for any particular market. In the European context, the reasons for wishing to establish a single European currency are purely political and have no grounding in which ever economic theory. On a general plane, the requirement calls for a single unit of account, when there may be a multiplicity of units of exchange all being commensurate in that one unit of account.

Generalization of this constituent element requires the insight that what is a currency for market exchange actually, and speaking more generally, is the language in whichever market communication takes place. Here, it is perfectly possible that market traders express their bids in different languages (i.e. currencies) and yet transactions can be readily concluded, if there is a common unit of account into which these different bids can be translated. Right now, as far as money is concerned, any credit card company serving customers in different countries does the same on a routine basis.

Obviously, research communication, which we have already identified as an exchange relationship in that ideas and concepts are being offered and considered for either further use, corroboration or rejection, require media of exchange. These media of communication, again, have to be compatible in a way that is similar to the monetary requirement for a common market area. There has to be one common unit of account, which makes the different communications commensurable.

In the context of scholarly exchange, this issue is rendered much more difficult than in the context of a European Monetary Union. What needs to be made commensurable is being expressed both in terms of language (such as an official languages accredited with the European Union) and other forms of effective communication, including mathematics, computer languages, but also languages that are not susceptible to any formal accredition procedure. As in scholarly communities there is a division of labour, there are also economies of scale in developing common concepts and common linguistic vehicles for smaller communities of scholars working in the same area or on the same subject matter or with the same set of ideas, data, etc.

In order to keep communication open, these scholarly networks need to be accessible for a wider community of scholars, and they very often are not, because remaining closed may allow for a competitive advantage in some funding process, as sometimes for purely linguistic reasons a monopoly in some area (which has no translation) can be claimed. If this practice takes hold, there is an incentive to break up the university research landscape and mold it into different language areas so as to create a sufficient number of monopolies each being able to claim particular preferantial treatment. This approach can only be undercut if no funding agency is allowed to follow such particularistic practices, which implies that funding priorities cannot be allowed to be put forward in terms of some specific language based paradigm or lingo. All the European Union tenders for research grants applications I have received over the last twenty four months were drafted as described here so as to grant preferential treatment to 
a very small group. They always described the research "methodology"10 in great detail so as to speak to a small group of scholars easily identified by insiders.

Finally, the principle of free access to markets can be readily translated into the European university landscape, and with respect to European initiatives, there is little disagreement here. The principle forms the core of the Treaty of Rome, and it has become increasingly obvious that it needs to be translated into the market of ideas as well. This conviction also seems to lie at the heart of the policies on the part of the European Union that this article deals with. The issue is not one of principle; but one of the forms the policies take.

\section{V.}

The brief historical survey over the history of European research universities pointed to the feature that even at the end of the nineteenth century, it was still very common that major research results would be published in text books. As a matter of fact, it was still common practice at Austrian universities until about the end of World War I that lectures would literaly consist in the reading of stencils that had been pre-approved by censorship. The university professor actually was not allowed to substantially depart from the pre-approved script, which is why well healed students would hire poor but academically qualified fellow students to sit in through the lecture and take the notes that were often required in order to receive the certification of having heard the lecture. The benign features of this peculiar arrangement consisted in providing heating and free education for destitute students who would otherwise not have been able to pay for either heat or lecture fees and to provide the well healed students with the opportunity to avoid the boring lectures, made boring by the imposing institution of censorship, and pursue their carreers otherwise, in the fraternities and the salons.

The less benign features of this arrangement have been sufficiently detailed in the literature. The description show that interference with the task of communication in the university, in this case through the most likely least thought of measure of requiring pre-approval, can have enormeous consequences. In this particular case, an entire future elite, being systematically barred from effectively attending university lectures, was groomed in terms of maintaining a distance to that institution of learning, and to take advice from other in all likelihood less qualified sources. The most likely source were morels. The insight from this episode is perfectly generalizable. When a university is no longer allowed to be its sole governing body with respect to how lectures are being delivered, who is being admitted, who is allowed to give the lectures at what time, what the lectures concern and how examinations are being handled, in all these instances likely infringement of the free process of communication can be expected. Only some of these infringements are benign. In the long run, the less benign ones will come to the surface belatedly, because all parties involved have an incentive to deal with the short term problems first and to delay handling the long term consequences of a particular intervention, as these long term consequences most likely are not understood by a large group of decision makers.

VI.

The foregoing display of historical features and vicissitudes in university development has not

10 Where method would be correct. 
been a systematic account of the development of university based scholarly exchange of ideas. There is no such a work, and my own exposition has drawn widely on a very large number of published and sometimes unpublished sources. Yet, it is not impossible to postulate a minimal canon of requirements for an effective order of scholarship, if we simply rely on our six constituent elements taken from ORDO theory and apply them accordingly.

1. Contractural freedom for the university landscape then must imply

a) for the relationship between student and university: free contractual choice: that means that both the student and the university can either chose or reject the partner trying to contract. A compulsory requirement to accept any student without an entry exam is certainly an infringement of academic freedom as traditionally understood. Traditional universities have used a combination of entry fees and rites of induction.

b) With respect to scholarship and the partners of exchange of ideas again, free contractural freedom has to prevail, which implies that side payments influencing the behaviour of individuals, in particular groups or organs not directly related to the decisions with respect to research and instruction should not be acceptable. If they were, freedom of research and instruction on the part of the individual researcher or group of researchers would become difficult to live, as free riders would use generous side payments and, undercutting normal channels of communication, would thrive on the published results made possible through the side payments. In this context, it should be kept in mind that scholarly communication, as defined above, is a risky business, the scholar always puts his or her reputation at risk. Results are offered for use, corraboration or refutation. The subsidized scholar has no such concerns, as his client is not his partner in exchange of ideas but rather the partner who underwrites the payroll of his penman. Hence, the subsidized psuedo participant in scholarly exchange disturbs the basic order of that exchange, acts as a free rider who cannot be sanctioned, as he has no stake in the proper functioning of the collective enterprise.

The guarantee of private property rights in the context of minimal guarantees has to be seen as an attempt to provide research universities with a means to recapture the benefits from public goods and externalities they generate. Since the examples given for the United States and for historical instances are not, so it seems, relevant today, we should be able to discern the underlying principle and thereby arrive at new and feasible solutions. In the simplest of reasonings, universities provide their students with enhanced human capital which is, consequently, subject to taxation under the income tax.

Income taxes will be outside processes of European tax harmonization and therefore tax instruments based on the individual income tax will still be possible as policy instruments in order to provide for university financing. What can be done here is fairly straightforward. To the extent that human capital is actually being provided by universities, student loans covering tuition fees can be extended on the basis of successful university entry exams, provided these entry exams have sufficient predictive value, and thereby the entire system of student loans and state fellowships can be privatized. That would give even state sponsored universities substantial room for re-learning the old game of competition.

With respect to research results, externalities and benefits from public goods are much less readily captured. The standard solution of granting universities a solid portion of the budget seems to be in question now, and a shaky stake in ever more questionable state budgets seems to be of little value for research and growth oriented university institutions.

Something better than shaky portions in state budgets is urgently called for. Since universities 
provide mainly public goods and externalities, advising them to seek more revenue from earning patents, royalties and the like is of little use. Internally, the engineers will cheer, but in most other disciplines patents are marginal and copyrights are either irrelevant or even dysfunctional.

In the social sciences, copyrigths are dysfunctional because the scholar wants his research findings to be made available to his colleagues and his students as readily as possible. Here, the cost of consuming research in terms of opportunity costs (what could you have done with the time you spent on trying to read this article?) are so exorbitant as compared to the conceivable royalties, that adding the royalties would only hinder that scholar's purpose. In these cases, gaining financial independence from an ever less interested state patron, and knowing full well that this patron will never endow its universities with the kinds of endowments that private institutions on the other side of the Atlantic Ocean have received from private donors in the past and still enjoy, will mean that remedies have to be offered that are only sensible in this peculiar European predicament.

State legislatures that have ballooned state sponsored universities beyond proportion and into tasks they were never made to fulfil, will now have to face what they have to face with every other industrial development experiment: they will have to come up with a stabilization plan. The stabilization plan, due to the distribution of voters in the case of universities will have to be meager.

So it will not be in cash, but it can be in terms of tax facilities geared to these particular institutions. What stuns every visitor of the United States and what stuns a careful reader of i.e. German university history prior to World War I is the extensive willingness of a generous and well healed public to give substantial funds to universities, even if these givings were subject to charity taxes. Prior to World War I, there were a wealth of foundations in the German language university landscape, supporting several universities outside the state budget. The peculiar form of financing the effort of World War I on the part of the central powers wiped out the material existence of these universities. These funds had been accumulated within a fairly short period of time, under fairly adverse tax legislation. With enlightened or only a little bit enlightened tax legislation, it should be possible to repeat the accomplishment.

For procedure we should note the following. Since it is not difficult to show for almost any university regulation that is state imposed how costly it is and how little benefit is derives, a wonderful marketing field appears. A framework agreement has to be arrived at with the never pleasable and always irritated state patron of universities to agree to a privatization action where every private pledge for the foundation to guarantee the university's existence will be matched by the state. Then you take one regulation after the other that the state has imposed opposed upon the university. It is by now a thick layer, which can be taken apart with an archeologist's care. For each of these a careful and sound cost benefit analysis is being prepared. The compound net cost/benefit is put into the endowment fund, and if the state should come out ahead, it is done to its credit. If it does not, getting rid of the regulation is marketed into a tender to be fetched by the highest bidder able to provide a better suggestion for a regulation, who will make an appropriate donation. The state has to match that donation. Thereby, a prudent university administrator should have no trouble in building up a foundation fund that will attract interest from people who have long sought to find a decent university where to fund a chair, launch a research initiative and the like or else, which is on most people's minds, send their children (ore grandchildren). Again, the strictest rules will have to apply to such donations, in order not to invite similarly awkward situations as the present ones back again and through the back door. 
The point of this scenario is to show that it is possible to emancipate European research universities from their increasingly unwilling state sponsors. Originally, the task of university foundation was a state task only to the point of getting the university founded and established with a charter. Intervening with university affairs is a fairly recent phenomenon, and we see it mostly in those countries where universities were doing very well before the intervening. Now that the rent has been reaped by politician who are by now long gone, it is time to get over with this awkward experience and re-build the universities to their former image.

The nutshell of this story, which we want to put in the form of a minimum requirement, is this: since a research university provides its output mostly in the form of public goods and externalities, it has to be financed in a form that is relevant to this output. To the extent that tax financed solutions do not work, substitute arrangements making use of tax deductions for charities and research may prove, based on precedent, to accomplish the task more effectively than direct budgettary appropriations.

If increased independence from government budgets is going to be part of the future of European research universities, it will be extremely important to develop a code of professional conduct for administrators that allows for distinguishing between the task of scholarly exchange of ideas, the production part of the company, and the task of securing funds, the financial part of the company. In between, there is a third aspect, what in an awkward way could be called the craftsmanship or commercial part of the traditional university, which is the notion of carefully dealing with the clients, i.e. the students, the future employees, the seekers of advanced degrees, and "extension", this important aspect which has become the third wing of the American land-grant universities. It is very difficult to make sensible statements on this topic except for mentioning it. We have very few examples of good professional conduct of university administrators that would shed light on the needs of the post-Maastricht period. It is perhaps wiser in this context only to mention and to re-iterate that those who take decisions have to be held responsible for their consequences in the long run, however, to the extent that university administrators take decisions who may be appointed for just one or two years, while those who may be held responsible for the decisions may be appointed for life, this arrangements of affairs will in the long run leave the university as a collective institution with many bad decisions for which nobody wants to be held accountable, and very few good ones, for which there will be many claimants. Worse still, this approach will prompt many a scholar with assets he deams to be highly appreciated in a context he can think of and his superior and colleagues think little of in the context they can think of, to leave the institution and look for a greener pasture. Although this may be the right course for many a departure, it may be very costly to the sacrificing institution with respect to quite a few.

Understanding their patron has become a major problem of most state sponsored European research institutions. Consistency, predictability and sometimes even honesty are wanted. Here, the simple conclusion can only be that divestiture is the only conceivable course of action. A state that does not take pride in its university institutions should get out of that activity right away, because, among many reasons, it is a costly activity and it will not profit from an unwilling patron. Different institutional settings can be readily imagined that are more conducive to enlightened university life, which after all not always to everybody's pleasure reverberates on social life in the community in which it operates. Yet, that is what pretty much everybody expects from a university, and one should therefore be willing to find a form in which universi- 
ty activity can be conducted without constant and sometimes very costly interferences from rather different bodies of government.

The more technical aspects of the next three criteria have already been extensively discussed previously, and I shall therefore now turn to section seven.

\section{VII.}

The field of European policies towards science and technology and the impact of sometimes other policies on the European research landscape is very difficult to evaluate in a comprehensive way, as these policies are extremely diverse, and sometimes, so it seems, obtusively hidden in policy documents that, of course, reflect the constitution of the European Union but are not necessarily tailored to the needs of the scholars who are supposed to respond to European Union initiatives. Since this chapter is devoted only to constitutional aspects of how to react to those initiatives, given your particular university environment, and furthermore what you can do about constitutionally changing your university environment so as to make it more suitable and susceptible to such policy initiatives, it may be sufficient to single out only two characteristics of European policy initiatives with respect to science and technology which go, indeed, to the core of the traditional research university. These two are readily identified. It is on the one hand the idea of matching funds, and it is on the other hand the notion of identifying core areas, typically combined with the idea of matching funds. In order to explain what actually happens, and in order to also illustrate the principle of subsidiarity which is here of immediate concern, let me try an example. Before I do that, let me recall the principle of subsidiarity:

In areas which do not fall within the exclusive competence, the community shall take action in accordance with the principle of subsidiarity only if and insofar as the objectives of the proposed action cannot be sufficiently achieved by the member states and can therefore by reason of the scale or effects of the proposed action, be better achieved by the community. (article III B (2)) of the EC Treaty.

Under a matching fund arrangement, let us assume that a university with an anthropology program called A that is also joined with a biology program called B in one department receives a notice from the university administration, that matching funding is to be expected if the A and B program could come up with a proposal that would allow the university to get matching funding for a general program called "human inquiry into our existence" which would have to involve at least three faculties. The university administration knows that is has a chance perhaps one in seven to catch a grant that would allow it to fund its research activities through an external source without compromising on the teaching activities. At the same time, that same university administration knows that it has never reaped any tangible benefit from the research activities of its faculty.

We noted earlier, that research universities are engaged in the production of public goods and externalities, which means that no existing university administration has ever reaped any direct benefits from any research activity ever conducted under its own auspices, other than by chance. In the usual course of things, this proposal is going to travel downstream to the level of the college. Let's keep in mind, the central university administration was willing to match the funds. In all likelihood, the dean of the college is also interested in matching the funds and 
also to tilt the balance between this awkward A and B department, people who could never agree in the first place. Now we have the interesting case that one seventh of an ECU in fact has already been matched by a total ECU at the university, that is one half of an ECU at the university level and one half of an ECU at the college level. That is an interesting multiplier indeed. It is interesting to note what is going to happen in the A and B department. Being confronted with these constraints, and being, of course, loched into their lifetime research program, also working on the basis of the agreements made with their chairman at the point of their hiring, research evaluations and promotion decisions, people will take decisions so as to make sure that they can conform to the new standards thus imposed, as these may trickle down research money, travel stipends and extra perks.

The impact of such a policy initiative can be extremely heavy, if institutions have not been used to similar treatment. In all likelihood, all the participant agents are acting in good faith.

\section{VIII.}

Since the policy instruments are the brain childs of those who came up with the policy goals, there is very little use in discussing the policy instruments separate from the policy goals. The instruments have been discussed and looked at in their various difficiencies in the preceding paragraph. We now continue with the issue of performance and its evaluation.

\section{A Point of Theory}

In trying to suggest an appropriate technique for analysing the performance of public enterprises thus described, we have to reckon with the many and different purposes governments try to pursue with them. As the preceeding discussion may have suggested, the definition of the purpose of a university as a public enterprises is mainly negative. It is easier to characterise them in terms of the purposes they are explicitly not suggested to serve instead of precisely establishing what the purposes are that they are supposed to fulfil. This may be a deplorable situation from the point of view of economic analysis; but we cannot reject the possibility out of hand that the apparent fuzziness of university purposes in most democratic societies is the very reason why they occupy such a prominent and increasing role in many economies, privatization programs notwithstanding. The implication for attempts at evaluating the performance of universities is that a technique of performance analysis has to be found that can serve as an envelope for the fuzzy purposes public entereprises in general and universities more particularly are fulfilling. Instead of clearly establishing performance criteria drawn from applied welfare economics and attributing them to public enterprises, a technique may be preferable that starts from the public enterprise itself and attempts at an increasingly more precise picture of the fuzzy set of objectives pursued.

The basic theoretical point of departure for this approach was introduced by Mancur Olson at a National Bureau of Economic Research conference in 1973 devoted to the measurement of economic and social performance. ${ }^{11}$ Olson's point of departure is the suggestion, that

11 See Mancur Olson, "Evaluating Performance in the Public Sector". In: Milton Moss, ed., The Measurement of Economic and Social Performance, Studies in income and wealth 38. New York and London: Columbia University Press for the National Bu- 
"governments are in fact as well as by reputation usually inefficient, and that this is mainly because they deal will collective goods and externalities." (Olson 1973, 359).

It should be emphasized from the start that Olson explicitly refers to technical (in) efficiency. His notion of efficiency has to be seen in the context of, e.g., the literature on production functions, and not in the sense in which it is used by members of the Chicago school such as the late George Stigler. ${ }^{12}$ This choice of efficiency concepts implies that public production, even where its methods have been shown to be inefficient for not reaching the production possibility frontier, may yet not be improvable in the Pareto sense because no better alternative is known that can readily be implemented. In terms of a transactions cost approach, this implies that public production, even where it is shown to be technically inefficient according to the performance analysis approaches, may still be efficient because unimprovable, since the transactions costs involved in this particular process of production are prohibitively high in rendering the internalisation of externalities infeasible.

Which are these areas of public production Olson is referring to? His examples include: law and order, defense, basic research, and pollution control (Olson 1973, 359), areas which form the new primary domain of public entrprises as opposed to the past smoke stack industries. More so than fifteen years ago when Olson made this suggestion, public enterprises today are increasingly retreating from the production of merely private goods and thriving where they contribute to the production of positive externalities and public goods, a contribution often made as a by-product of traditional production. Research laboratories with spin-offs for defense, passenger railroad to substitute for car transport and universities contributing to basic research are all cases in point and mark public entrepreneurship to which all Western states cling irrespective of privatization programs they may otherwise be engaged in.

The inherent inefficiency to which Olson pointed is unavoidable, because it is inherent in the very definition of a public good. These inefficiencies are of two kinds. To the extent that noone can be excluded from the consumption of the good, the true preferences for the provision of the public good are difficult to establish. Hence, in assessing the performance of public production, we never know whether too little or too much is being produced. The second source of inefficiency is more difficult to handle. Even where governments provide too little or too much of a particular public good, they may do so perfectly efficiently in terms of reaching the production possibility frontier. The condition of jointness of consumption implies that the marginal calculus breaks down and that measuring of outputs becomes infeasible. As Olson puts it:

"The very characteristics of a collective good that make it a kind from which nonpurchasers cannot be excluded, also make it a kind of which the output is not in the form of divisible units that can be readily counted." (Olson, 1973, 362).

reau of Economic Research 1973, pp. 355-384 and 397-409.

12 See the interchange by Leibenstein and Stigler on X-Inefficiency in the American Economic Review. George J. Stigler, "The Xistence of X-Efficiency". American Economic Review, 66, 1976, pp. 213-216. Harvey Leibenstein, "X-Inefficiency Xists: Reply to an Xorcist'. American Economic Review, 68, 1978, pp. 203-211. 
Since evaluating the performance of public production requires the attribution of some values to the output, performance analysts face a grave dilemma:

"The customer (demanding a private good, J.B.) is in a position to estimate the value to himself of an additional supply of service from a firm because he can experiment with different levels of purchase. His estimate of the value of the goods shows up in the marginal revenue the firm receives. By contrast, in the case of a collective good going simultaneously to many individuals, the individual consumer cannot take more or less to see how that effects his wellbeing." (Olson, 1973, 363).

This second difficulty leaves us with the dilemma that the production functions for public goods and externalities cannot be established and production cannot be evaluated in terms of technical efficiency (Olson, 1973, 405). Since this will also be true when public enterprises simultaneously engage in the joint production of private and public goods, a different approach will have to be devised.

While Olsons's point is extremely important and very basic, it does not lead immediately to ready made solutions to improve the efficiency of public sector production. His own suggestions (selective and experimental pricing and spot controls) might help on occasion, but if systematically used would likely invite inefficient responses on the part of the public institution thus controlled. ${ }^{13}$ Not surprisingly, agreement could not be reached at the NBER conference, and Olson's important paper seems not to have had major consequences so far. Fortunately, a completely different strand of economic literature has developed right to the point that it can be linked up with Olson's approach.

\section{$\mathbf{X}$.}

In however way you want to turn the pages of history, European universities now look different from how they looked, for instance, five years ago. The European initiative has had an impact, and we can look at the impact from different points of view, but we have to somehow accept and comprehend that with the European Union initiatives also arrived the notion of rating research. Now, to begin with, rating research has, of course, been with the European research universities since the very beginning. The most visible sign of appreciation has always been the flow of students coming to a particular professor. Interestingly enough, there is another European Union initiative seizing just upon that issue and channeling the flow of students to particular professors under their program control. Whether this particular program (Erasmus/Socrates), certainly not in accordance with university constitutions, is anywhere in compliance in Europe, is certainly beyond my expertise. Yet, it is obvious that depending on circumstances, psychology as a field may be a very important field in one university, and sociology in another, where there may be universities where economics is absolutely beyond question, whereas marketing is not, there may yet be another university in which marketing is the prime focus, and economics is of little significance. The issue in this context is how European policies impact on these situations, for instance policies towards research and technology

13 See William S. Peirce, "Bureaucratic Failure: Incremental Drift from Public Goods". Cleveland: Case Western Reserve University, Department of Economics, Working Paper Nr. 32, 1977. 
in the European research landscape.

This scenario has been described in such an awkward way in order to show what awkward problems need to be addressed if one wants to compare the quality of different university institutions with respect to their output across the different Member States of the European Union.

For starters, keep in mind that the Treaty of Maastricht has excluded the sphere of culture from what is to be harmonized. Yet, at the same time and at the time of writing as well as signing and ratifying the Treaty of Maastricht, one of the most popular programs ever launched by the European Union was the Erasmus program of student exchange, now being superceded by the Socrates program. This program was much more succesful than the, for instance, common agricultural policy, since its excess burden is minimal, its real expenditure is equally minimal, but its impact is very strong and somehow in tune with the ambitions of politicians in every single Member State of the European Union. A lucky find, indeed.

In this benign context, however, students need to transfer credits. Students actually have to be sent to roughly equivalent institutions if they are to transfer credits, and that requires that institutions be looked at from the point of view of whether their output is comparable. Hence, they need to assess that output in quantitative terms. Once you are at it, budgettary keys can also be hooked onto that same assessment criterium and the program receives an additional impulse because of the budgettary need to perform well in the assessment as provided by the program ascessors.

How does the university with the strong marketing program and the insignificant economics program fare, in this context, as it allies itself with an opposite partner? From the point of view of the students, there should be a perfect match. The strong marketing student will wish to also have exposure to strong economics and vice versa.

From the point of a allying oneselves with a view to rating, the weak departments have a strong incentive to allying themselves with those that, although still acceptable to their students, are certainly not stronger than they are themselves. There is, then, a run towards the lowest common denominator of general acceptance.

Since the incentives although on the whole not very important on the margin are still strong, our previous example showed how one ECU could generate efforts well in excess of seven under plausible assumptions, this run for the smallest common denominator will also be translated into university administrative decisions which, as we have seen before, are not tied to the decisions of researchers who have to guard their reputation. The up shot of this observation is that the whole scenario holds promise of poor administrative decisions, but also of decisions of supporting lower ranking scholars that are neither to the benefit of students nor to the benefit of the universities to which both these scholars and the students belong.

A stunning feature of the European funding policies is the ability to create clienteles for rent seeking games at the expense of other juristisdictions. This fairly strong point can, again, be illustrated in a step wise procedure. Take seven countries who are joined in the European Union, and let there be doubt about the federal institution (commission or council) on whether there is a prerogative for a particular type of policy. Hence, a tentative voluntary program can be launched on behalf of the Union. In order to pull this off, the initiating body will have relied on program proposals fed into its bureaucracy by applying and supplying institutions, interest groups for diverse ends concentrating on that particular field in question, for instance policies 
towards research and technology in the European research landscape.

Take a particular discipline that, for the sake of simplicity, has always been defined as consisting of seven different fields. Let a sufficient minority of one field combine and put in for a program that will define that particular sub-field as one of the main areas of a European research initiative. Given the particular scenario (the one to seven multiplier scenario) sketched out above, all of a sudden, one out of these seven fields can grow beyond proportion in some universities, most likely the better regarded ones, and still because they are regarded due to the common and public reputation to which all of the disciplines have contributed. At this point, due to the matching mechanism, that one discipline grows beyond proportion in those successful faculties, and it may be very difficult for competing faculties to chose a counter strategy. As a matter of fact, given the numbers involved, the sudden increase in funding (and consequently positions) in that one particular field will lead to young scholars' decisions to move into that field, or at least close to it, so as to have a chance in future appointments. Since by their sheer weight in due course the scholars attached to this "centre of excellence" will dominate professional organizations, research councils and the like, they can, to a certain extent, perpetuate the success.

Nothing in the description of this scenario has been said about the quality of the research involved. What has been said is that the mechanism of the programs launched by the European Union leads to a change in the budgettary flows in such a way that substantial shifts in academic pursuit are the likely outcome.

The way we have to look at such shifts is not immediately obvious. From a simplistic economic point of view, the better buck buys the better article, and consequently, what the heck is the argument about? The marginal utility argument (the better buck ...) is about private goods, about the spending decisions of private individuals or well identified groups with well identified preferences that can enjoy the marginal benefits of acquiring particular goods or services. Universities, as we have learned early on in this article, are above all in the business of providing public goods and externalities, for which, as I have tried to show with Mancur Olsen's help, in the previous section, the marginal calculus can break down. Worse than breaking down, the lack of systematically being able to employ the marginal calculus opens opportunities for rent seeking, which can have consequences for the very ability of an institution to provide the core of public goods and externalities needed for a particular infrastructure of, for instance, a Member State of the European Community. If we just take, for the sake of an example, the seven chair departments postulated previously, and we think that chair $\mathrm{F}$ is joining with all the other chairs $\mathrm{F}$, and a sub group of these chairs F receives the EU grant, the implication is that the sub disciplines represented by chairs A, B, C, D, E, and G will lose not only relatively to $\mathrm{F}$, but also absolutely, since we had assumed the total university budget to be given, and there was a multiplier of 1:7.

Since the matching funds for the F group come out of a generally assumed to be stable but typically shrinking general budget, it is necessary to show by some means of documentation why the other subject areas have to release funds to the privileged one. It will be necessary to show that the privileged area actually, by some measure, is deserving more funds than the others, and this excercise will somehow have to be carried out a) with a view to future initiatives to receive matching grants and $b$ ) with a view to the ability of the privileged department to perform according to the criteria to be found. Thirdly, European Union guidelines will have to be observed carefully in order to fullfil the goal pursued under a. 
In this proposition of the task of the university administrator, the preservation of the field as it traditionally has been taught does not figure anywhere. This could be considered an advantage if the new way of conducting research in that particular subject area where somehow the response of a scholarly exchange as to the merits of those subject areas, which it is not among our assumptions of this scenario. In fact, this scenario leaves ample space for entire Member States of the European Union to leave out entire subject areas from their curricula and research activities, and certainly without at any point of decision consciously wishing to do so.

As a preliminary conclusion, we can note that the scenarios of European policies towards research in science and technology have the potential to skew the decisions of identifiable decision makers so as to obfuscate the opportunity costs of their decisions and to emphasize sometimes small marginal benefits.

The introduction of the so-called Monnet professorships is an interesting case in point. The guidelines for the selection of Monnet professors call for nominations, either by name or by subject area or by both through the head of the university with the consent of all the reporting organizational parts (college, faculty, department, supervising professor), and the apparant idea of the whole initiative is to create a breed of young European minded professors in the schools. This objective it may very well achieve, but the opportunity costs, again, may be very high. Let us take a look at how such a procedure takes place in a typical Member State of the European Union. Consider a state monopoly system of the university landscape (most European Member States have such a system) with the consequent depressed salary levels and high regulatory burdens.

Dynamic administrators have little chance in retaining promising young staff, and they have an eye on keeping promising staff with an ability to network in European circles so as to attract grants money. (this would, again, follow the 7:1 matching system as explained above.) Obviously, in a department composed of the seven sub-disciplines A through $\mathrm{G}$, the choice of a suitable candidate will have to focus on a young person in set $\mathrm{F}$, who has not yet shown credible signs of being an achieving scholar but who has shown signs of being able to network and create funding relationships. The first point is important. If sufficient qualities in research and teaching as well as conceivably extension exist, this person is a hot asset and cannot be home bidded from an international market, which the European Union provides, among others through the Treaty of Rome, the re-enforcement of that treaty through the Treaty of Maastricht and, last but certainly not least the Erasmus and Socrates programs. The successful candidate who has been selected in the way suggested will bypass many of his competitors in his age group who have chosen different carreer paths. This will not go unnoticed, and the departments $A$ to $D$ and $G$ will be further weakened by not being able to attract hard working if conceivably rather less "European" minded future university professors. Since in most Member States of the European Union, administrators who take the Monnet decisions are sitting for only one or two years, they have a strong incentive to further the interests of their own - within reason of their colleagues - and look at the future consequences, notably with respect to the entire research landscape and to what students can now reasonably expect, with less intensity of purview.

The Monnet program then will have produced an interesting group of people who will interact with the traditionally appointed university professors, but the long term impact of the program on the progress in science and technology in the European Union will be very difficult to 
assess. It may be impossible to assess, although the damage of the program may be substantial. The main damage lies in breaking the traditional carreer patterns on which life orienting decisions had been based, which is important in the case of researchers who tie their human capital to their research outlook, and it is also important with respect to guaranteeing a reliable transfer of knowledge to the next generation. Several European Union members are no longer able to transfer the common European knowledge in my own discipline, economics, to the next generation, as they lack, to name just the simplest instance, a commonly accessible source for tapping the internationally common pool of (in my case: economic) knowledge.

\section{XI.}

This essay has been difficult to read because the author had to lead the reader to conclusions that are by no means obvious, and that have not at all been discussed in the popular or academic press. Actually, the findings here presented cannot readily be translated into research paradigms that could be conducted so as to survive, in their output, standard review procedures for research to be published.

However, I submit to the reader the question: what else can we do? The problems pointed at in this essay are by no means obvious, and they spring from a mind trained in thinking about orders of systems, when most economists are not even trained in terms of thinking about systems but rather in terms of processes within the systems they have learned to know since they were high school students. The bread and butter applications of my suggestions are more tangible than what could have been accomplished through a sociological approach, they are also more tangible and, I think more palatable than could have been accomplished through a post-modernist approach, and yet I remain unhappy about not being able to systemattically have this analysis be screened by an audience that actually knows the subject ${ }^{14}$ The sample for a critical inquiry about the merits of my study would have to be a group of economically trained university administrators. This group does exist, and I intend (with the consent of the editor) to conduct such a survey. If one takes a world wide view, a surprisingly large number of economists have actually ended up as university presidents. The survey would emphasize the issue of whether my rendition of the problems European research universities face vis á vis the current and upcoming European initiatives, is skewed, wrong headed or to the point.

Since most of the actual consequences of European Union initiatives described in this chapter are difficult to ascertain in clear quantitatives terms, and since there are certainly no data bases which can be readily accessed by ill-equipped students ready to finish a disseration project within their allotted time, where the allotted time again has no bearing on the importance of the subject, it is difficult to dispute my story. But this is deeply troubling to me, as I am one who should like to have his story disputed if it is not correct. In this case, it is difficult to dis-sociate the personality of the writer from the article that is being written. One way, so far the only way

14 In my attempts to discuss these matters, I have been stunned by the lack of knowledge of well known university professors about the circumstances of their professional existence. In particular, I was stunned by the fact that more is always thought to be better than less, without due regard to whether more is coming, and why the less is being accepted. 
I know, there may be others, is the approach to influence studies, Peter Senn ${ }^{15}$ has pioneered. This is one approach addressed to the question raised. It is not the only possible approach, and it is not the last approach.

The main point of this study, that the European research university, given the shape of the current programs of the European Union, is being weakened by the European Union, will only be demonstrable after the readers of this essay have long passed their prime.

XII.

In this essay, I have tried to show that the European Union inititiatives towards science and technology, ostensibly in the interest of promoting employment and growth through technological advancement, have side effects that undermine the very purpose at which they aim. The funding formula and the way the programs are launched undermine the ability of leading research universities to be leading players in the international fields that is, of course, not dominated by European Union research priorities. The only way to make the program successful is, indeed, to make it universal, which is out of the question. More specifically, we have taken note of a number of points which are worth taking stock of at the end of this long essay. They do not quite reveal the impact of the argument, but some preliminary statements may well be formulated on the basis thereof.

1. At the traditional European research university, next to the publication of doctoral disserations and public examinations throughout, open competition for university positions and the prohibition of inhouse promotions (which are known to lead to nepotism) form part of the heritage of reputation preservation.

In no known case was there an emphasis, during the era of the traditional European research university, on trying to organize the competitive process for resources around topics of inquiry of themes of research, as such attemps would necessarily skew competition in terms of the specific competitors aware of their prior advantage.

Secondly, with respect to scholarly communication we can note:

2. Only if the participating scholars and scholarly institutions are roughly endowed with the same bundle of rights can an unstrategic process of scholarly communication take place and continue with success.

15 - Senn, P. R., "Where is Althoff? Friedrich Althoff in English: How Has He Feared", in: Backhaus, J. (guest editor), "The Economics of Science Policy", Journal of Economic Studies, vol. 20, No. 3/4, 1993a, pp.201-261.

- Senn, P.R., "What has Happened to Gustav Schmoller In English?" History of Economics Society Bulletin. 11, No.2. (Fall) 252-294. Original paper read the symposium "Gustav von Schmoller und die Probleme von Heute", 24-27 June, 1988 in Heilbronn, Germany.

- Senn, P.R., "Gustav von Schmoller in English: How has he Fared?" History of Economic Ideas. Combined Vols. I/1993. No.3 and II/1994. No.1: 267-329. 
3. Joint financing arrangements stemming from decisions involving the European Commission and the European Council, and the consequences thereof, can lead to serious impairment and conceivably a break down of the scholarly community, the reliability of interchange and the unquestionability of scholarly motives in entering into scholarly communication.

New forms of financing universities would give even former state sponsored universities substantial room for re-learning the old game of competition.

4. This scenario is credible. In one case, it can be demonstrated that substantial funds had been accumulated within a fairly short period of time, under fairly adverse tax legislation, and yet being sufficient to feed an entire university (the University of Frankfurt on the Main).

With enlightened or only a little bit enlightened tax legislation, it should be possible to repeat the experience.

5. The mechanisms of the programs launched by the European Union lead to a change in the budgettary flows in such a way that substantial shifts in academic pursuit are the likely outcome.

6. The scenarios of European policies towards research in science and technology have the potential to skew the decisions of identifiable decision makers so as to obfuscate the opportunity costs of the decisions and to emphasize sometimes small marginal benefits.

7. The difficulty in forming an opinion about the relevance and significance of European research policies lies in the impossibility of economists taking a point of view. In this sense Max Weber ${ }^{16}$ has greatly helped in writing this article.

16 Max Weber, "Wissenschaft als Beruf". In: Wissenschaft und Politik als Beruf.

Tübingen: Mohr, Siebeck 1919, 1983 (Max Weber Gesamtausgabe, vol. 15-2). 


\section{Literature}

- Arruñada, B., "The Economics of Notaries" , European Journal of Law and Economics 3.1, (March) 1996, pp. 5-37.

- Leibenstein and Stigler, "X-Inefficiency", in the American Economic Review. Stigler, G.J., "The Xistence of X-Efficiency". American Economic Review, 66, 1976, pp. 213-216. Harvey Leibenstein, "X-Inefficiency Xists: Reply to an Xorcist'. American Economic Review, 68, 1978, pp. 203-211.

- Möschel, W., "Corporation Policy from an ORDO Point of View". Chapter 7 in: Peacock, A. and Willgerodt, H. (eds.) German Neo-Liberals and the Social Market Economy, New York: Saint Martin's, 1989, pp. 142-178 (154-155).

- Olson, M. "Evaluating Performance in the Public Sector". In: Moss, M. (ed.), The Measure ment of Economic and Social Performance, Studies in Income and Wealth 38. New York and London: Columbia University Press for the National Bureau of Economic Research 1973, pp. 355-384 and 397-409.

- Peirce, William S., "Bureaucratic Failure: Incremental Drift from Public Goods". Cleveland: Case Western Reserve University, Department of Economics, Working Paper Nr. 32, 1977.

- Senn, P. R., "Where is Althoff? Friedrich Althoff in English: How Has He Feared", in: Backhaus, J. (guest editor), "The Economics of Science Policy", Journal of Economic Studies, vol. 20, No. 3/4, 1993a, pp.201-261.

- Senn, P.R., "What has Happened to Gustav Schmoller In English?" History of Economics Society Bulletin. 11, No.2. (Fal1) 252-294. Original paper read at the symposium "Gustav von Schmoller und die Probleme von Heute", 24-27 June, 1988 in Heilbronn, Germany.

- Senn, P.R., "Gustav von Schmoller in English: How has he Fared?" History of Economic Ideas. Combined Vols. I/1993. No.3 and II/1994. No.1: 267-329.

- Starbatty J. and Vetterlein, U., "Forschungs- und Technologiepolitik in der Europäischen Un 
